\title{
PROCEEDINGS OF THE \\ NINETEENTH INTERNATIONAL \\ MACHINE TOOL DESIGN AND RESEARCH \\ CONFERENCE
}




\title{
PROCEEDINGS OF THE NINETEENTH INTERNATIONAL MACHINE TOOL DESIGN AND RESEARCH CONFERENCE
}

held in Manchester, 13th - 15th September, 1978

\author{
Edited by \\ B.J. DAVIES \\ Professor of Manufacturing Technology \\ Department of Mechanical Engineering \\ University of Manchester Institute of Science and Technology \\ Manchester
}

\begin{abstract}
DEPARTMENT OF MECHANICAL ENGINEERING, UNIVERSITY OF MANCHESTER INSTITUTE OF SCIENCE AND TECHNOLOGY, MANCHESTER
\end{abstract}

in association with

M

Macmillan Education 
(C) Department of Mechanical Engineering,

University of Manchester Institute of Science and Technology, 1979

Softcover reprint of the hardcover 1st edition 1979 978-0-333-26436-2

All rights reserved. No part of this publication may be reproduced or transmitted, in any form or by any means, without permission

First published 1979 by the

Department of Mechanical Engineering, University of Manchester Institute of Science and Technology, P.O. Box 88, Manchester, M60 1QD

in association with

The Macmillan Press Ltd

London and Basingstoke

Associated companies in Delhi Dublin Hong Kong Johannesburg

Lagos Melbourne New York Singapore and Tokyo

British Library Cataloguing in Publication Data

International Machine Tool Design and Research Conference, 19th, Manchester, 1978

Proceedings of the Nineteenth International Machine Tool

Design and Research Conference held in Manchester 13thi15th

September, 1978. 1. Machine-tools - Design - Congresses

I. Davies, B. J. II. University of Manchester Institute of

Science and Technology, Department of Mechanical

Engineering 621.9’02 TJ1180

ISBN 978-1-349-81414-5 ISBN 978-1-349-81412-1 (eBook)

DOI 10.1007/978-1-349-81412-1

Produced in the City of Oxford by Oxprint Limited 


\section{Nineteenth International Machine Tool Design and Research Conference 13th - 15th September, 1978}

\section{CONFERENCE ORGANIZING COMMITTEE}

Chairman: Professor B. J. Davies

\section{POLICY COMMITTEE}

Professor S. A. Tobias (Birmingham)

Professor W. Johnson (Cambridge)
Professor J. M. Alexander (Swansea)

Professor F. Koenigsberger (UMIST)

ORGANIZING AND REVIEWING COMMITTEE

Professor B. J. Davies

Dr. C. F. Noble (Deputy Chairman)

Dr. W. Graham

Dr. R. G. Hannam

Dr. G. Barrow

Dr. M. Burdekin

Dr. J. Hawkyard

Dr. S. Hinduja

Dr. K. Rathmill

ORGANIZING SECRETARY

Mr. R. Kirk 


\section{CONTENTS}

Opening Address Dr. D. S. DAVIES, MA, BSc, PhD

\section{NC CONTROL SYSTEMS}

Chairman: Dr. E. Merchant

(Cincinnatti Milacon Inc.)

Development and present level of numerical controls. H. BECKER

Principle and examples of a modular multiprocessor NC system. G. STUTE and H. WORN

Software for a computer numerical control system designed for adaptive control research. D. H. MALTBY and H. R. MARTEN

A microprocessor controller to provide low cost numerical control.

R. H. WESTON and G. P. CHARLES

\section{DRIVES FOR NC MACHINES \\ Chairman: Dr. R. Bell \\ (University of Loughborough)}

Printed circuit motor feed drives for a C.N.C. lathe. A. J. WILKINSON,

G. E. WILSON and R. A. KINNIN

Feed drive system on large NC machine tools. P. DUFOUR and R. GROPPETTI 47

Computer aided design of closed loop controlled electrical feed drives.

G. STUTE, U. ACKERMANN and K. H. BOBEL

Safety aspects in design NC turning machines. K. FELTEN

\section{SOFTWARE FOR NC MACHINES \\ Chairman: Dr. S. K. Bhattacharyya \\ (University of Birmingham)}

An open loop C.N.C. lathe with optimised turning parameters. A. M. ROBERTS 71

Stand-alone interactive computer systems for N.C. tape preparation. R. A.

BILLET and D. GRAHAM

SPAM: A software package aiding the manufacturing with $\mathrm{NC}$ machine tools.

R. BEDINI, A. DEL TAGLIA and P. TONI

MACHINE ELEMENTS

Chairman: Mr. H. G. Harris

(Staveley Engineering)

Low cost externally pressurized air-bearings. Ir. L. DEVRIEZE and Prof. R. SNOEYS

Performance characteristics of hydrodynamic journal bearings with rolling pads. M. MALIK, R. SINHASAN and D. V. SINGH

The friction characteristics and the sliding stability of machine tool slideways which employ PTFE-Metal composite materials. R. BELL and O. ANLAGEN

\section{MACHINE ELEMENTS}

Chairman: Prof. D. S. Ross

(University of Strathclyde)

The prediction of plate deflection and radial gripping force for a three jaw diaphragm chuck. J. CHIDLOW and D. J. BILLAU

The measurement of gripping force and slip torque of components held by an expanding mandrel. J. A. G. KNIGHT and D. J. BILLAU

Face drivers as a modern gripping tool operational limits - Design and performance. M. SADOWY and H. SCHMID 


\section{MACHINE DESIGN INCLUDING CAD \\ Chairman: Em. Prof. F. Koenigsberger}

(UMIST)

Design conception of hierarchical modular construction - manufacturing different kinds of machine tools by using common modules. YOSHIMI ITO and

YOSHITARO YOSHIDA

The elastic behaviour of mechanical press machines. Dipl.-Ing. H. BLUM

CAD/CAM system for roll pass design. H. KOZONO

Computer aided progressive die design. SEIJI NAKAHARA and FUMIO ASUKE

\section{VIBRATIONS (INCLUDING NOISE) \\ Chairman: Dr. A. Cowley \\ (UMIST)}

Validation of Audiometry in the machine tool industry. J. CHARMAN and

G. J. McNULTY

The accuracy of noise measurements on machine tools under practical conditions.

N. PARKIN and G. M. TOMLIN

A method to determine the chatter threshold. M. RAHMAN and Y. ITO

Optimum design procedure of dynamic damper for machine tool structures.

Y. FURUKAWA and S. SHIOZAKI

FORMING 1

Chairman: Prof. W. Johnson

(University of Cambridge)

Smooth edge blanking and piercing using conventional presses. J. C. WESTWOOD An experimental study of the double cropping process. M. H. M. AHMED and M. K. DAS

Fine bending with counter pressure. T. NAKAGAWA, V. CUPKA and K. SUZUKI

Experiments into the inertial deformation of clamped rectangular, square and triangular diaphragms. S. K. GHOSH and F. W. TRAVIS

FORMING 2

Chairman: Prof. W. Johnson

(University of Cambridge)

A computer-controlled simulation of hot working by the flat compression test on a high speed servo-hydraulic testing machine. R. KASPAR and

O. PAWELSKI

Punch load requirements in warm extrusion of steel. U. DIETHER 255

Pressure distribution and friction in extrusion containers. B. LENGYEL and D. MUTLU

Ribbon winding of metal forming dies with different elastic properties of core and coil. JENS GRONBAEK

COMPUTER AIDED PLANNING

Chairman: Prof. R. H. Hollier (UMIST)

CAPSY - A dialogue system for computer aided manufacturing process planning. Prof. Dr.-Ing. G. SPUR, Dipl.-Ing. H.-M. ANGER, Dipl.,-Ing. W.

KUNZENDORF and Dipl.-Ing. G. STUCKMANN

A computer based approach to Heuristic scheduling. R. W. CLIFFE and

B. R. McMANUS

Computer aided estimation of the manufacturing time for turned components.

E. A. ORADY, I. YELLOWLEY and R. W. NEWCOMBE 


\section{FLEXIBLE MANUFACTURING SYSTEMS}

Chairman: Mr. D. McPherson

(National Engineering Laboratory)

Estimation of handling cost reductions due to layout changes. ALLAN S. CARRIE

Computer-aided material handling in flexible manufacturing cells. Prof. Dr.-Ing.

G. SPUR, Dipl.-Ing. H. RITTINGHAUSEN and Dipl.-Ing H. SINNING

Digital Simulation of a proposed flexible manufacturing system. W. W. CHAN and

GROUP TECHNOLOGY

Chairman: Prof. R. H. Thornley

(University of Aston in Birmingham)

Group Technology in UK Foundries. T. D. LAW and R. H. THORNLEY 333

Is the NC lathe the most economic solution in every case? Dr.-Ing. PETER DIETZ 341

Suitability Testing for group technology. G. F. PURCHECK and E. OLIVA-LOPEZ 353

A management tool for predicting the benefits to a company of group technology.

P. C. T. WILLEY and B. G. DALE

METROLOGY

Chairman: R. M. Burdekin

(UMIST)

Continuous measurement of linear motion errors in single tool cutting.

P. VANHERCK, K. BAGIASNA and J. PETERS

Surface Roughness Measurement: Alternatives to the stylus. T. R. THOMAS 383

A study on the effect of the structural vibration of a machine tool to the

circumferential surface roughness. K. MITSUI and H. SATO

\section{INSPECTION}

Chairman: Dr. D. J. Whitehouse

(Rank Taylor Hobson)

What is a DCC inspection machine? A. T. SUTHERLAND and D. A. WRIGHT

The use of a microprocessor system for on-line quality control in manufacturing.

D. GRAHAM and K. M. T. OLDHAM

Inaccuracies of large crankshafts (Causes, Measurement and Correction).

G. J. TRMAL and G. B. THOMPSON

METAL CUTTING 1

Chairman: Prof. C. Andrew

(University of Bristol)

The application of polycrystalline compacts for ferrous machining. S. K.

BHATTACHARYYA, D. K. ASPINWALL and A. W. NICOL

The performance of double margin drills with both margins cutting. D. J. BILLAU,

P. F. McGOLDRICK and W. B. HEGINBOTHAM

The assessment of tool life in peripheral milling. I. YELLOWLEY and G. BARROW

METAL CUTTING 2

Chairman: Prof. A. W. J. Chisholm

(University of Salford)

Novel ways of improving the performance of sawing operations. P. J. THOMPSON and R. A. MALIN

Cutting process of plastics by thin knives. YOSHIHARU NAMBA and HIDEO TSUAWA

Improvement of machinability and grindability induced by means of hydrogen addition for the material to be cut and grind. K. KISHI, H. EDA and H. UENO 
VIBRATIONS

Chairman: Prof. J. Peters

(Instituut voor Wentingkunde, Belgium)

Circular saw vibration during initial engagement. D. S. DUGDALE

Analysis and application of the electro-magnetic servo damper. YOJI OKADA

Optimum vibration of vibratory feeder loaded with handling parts. KATSUMI SAKAGUCHI

A new load cell dynamometer for measuring the dynamic cutting coefficients.

ECM 1

Chairman: Mr. A. E. De Barr

(MTIRA)

Fine hole drilling using electrochemical machining. JOHN BANNARD

Further effects of process parameters on the incidence of sparking in electrochemical machining. S. J. EBEID, E. M. BAXTER and C. N. LARSSON

An investigation on the characteristics of electrolytic superfinishing. S. M. SOLIMAN, H. A. MAKSOUD and M. LAWENDY

ECM 2

Chairman: Prof. J. R. Crookall

(Cranfield Institute of Technology)

Residual stresses in workpieces after peripheral electrochemical grinding.

J. ATKINSON and C. F. NOBLE

Electrochemical effects on shape reproduction in electrochemical machining. C. N. LARSSON and K. MUZAFFARUDDIN

EDM

Chairman: Dr. C. N. Larsson

(University of Strathclyde)

Study on the high speed machining by EDM using a moving coil head type feed control. T. MASUZAWA, K. TANAKA and M. FUJINO

The effectiveness of non-rectangular current-pulse forms in electro-discharge machining. C. J. FEENEY and J. R. CROOKALL

The use of acoustic techniques for monitoring and controlling the E.D.M. process. M. F. EL-MENSHAWY, S. K. BHATTACHARYYA and P. A. WOODROW 559

In process optimization of electro-discharge machining. Ir. J. P. KRUTH, Prof. R. SNOEYS and Dr. Ir. H. VAN BRUSSEL

\section{LASER PROCESSING AND FRICTION WELDING Chairman: Prof. B. J. Davies (UMIST)}

Materials processing with a high power laser. A. F. TAYLOR

Machine design and thermal aspects of the friction welding process. M. G. KIRKHAM, P. D. SMITH and P. K. WRIGHT

Some aspects of material hardening with pulsed laser beams. VLADIMIR S.

Crush dressing at full wheel speed. T. R. A. PEARCE, T. D. HOWES and C. ANDREW 599
The influence of diamond geometry on the stability of the grinding wheel dressing process. N. P. FLETCHER and H. MADEN

\section{GRINDING 2}

\section{Chairman: Mr. G. Sweeney}

(MTIRA)

Measurement of visible defects of a ground surface. G. TRMAL, E. HEFFORD, B. MANNING and H. KALISZER

A study of the heat flux at which burn occurs in creep feed grinding. J. W. POWELL and T. D. HOWES

Metallurgical effects associated with grinding. A. TORRANCE

Grindability Study of CBN wheels. S. K. BHATTACHARYYA and K. K. HON 


\section{OPENING ADDRESS}

PRESENTED BY Dr. D. S. DAVIES, MA, BSć, PhD.

Chief Scientist at The Department of Industry, UK

Prepared in collaboration with

Mr. I. J. Lawrenson

I am delighted to have the opportunity to give the opening address at this, the latest in a highly successful series of conferences. I am particularly pleased to be at UMIST, which even a Liverpudlian like myself grudgingly admits to be in the forefront of Technological Institutes in this country.

Sitting where I do in the Department of Industry, I not infrequently feel like the cellist at Covent Garden who, after many years of diligent bowing, actually managed to see the opera on stage, and was amazed at the action going on! So I always welcome the chance to come and take part in meetings like this today and to hear what you have to say.

We are all concerned in this country to see an improvement in our industrial productivity, and the machine tool industry is of course of central importance. The industry is a major one, employing more than 50,000 people now, although it has decreased from its peak of 81,000 in 1971 . Overall the industry has made much progress and a report published last week stressed that it did not deserve its lame duck image. (Machine Tool Manufacturers' ICC Business Ratios). However, in the field of numerical control the UK was originally well up with the leaders, lying behind the USA; this position reflected the sizes of the aerospace industries where, of course, NC began. In the international league table we are still near the top (Fig. 1) although we have been overtaken, notably by Japan. But it is noteworthy that the ratio of our

Fig. 1. N.C. MACHINE TOOLS IN VARIOUS COUNTRIES

$\begin{array}{lcc}\text { ESTIMATED NO. } & \text { \% OF TOTAL } \\ \text { USA } & 40000 & \text { MACHINES } \\ \text { USSR } & 24000 & 0.9 \\ \text { Japan } & 14000 & \\ \text { UK } & 10000 & 1.27 \\ \text { W. Germany } & 8000 & 1.09 \\ \text { Italy } & 3000 & 0.54 \\ \text { France } & 4000 & 0.55 \\ \text { FaCHINE TOOLS } & 0.3\end{array}$

(Metalworking Production: Fourth Survey)

Fig. 2. TABLE SHOWING DISTRIBUTION OF N.C. MACHINE TOOLS NO. OF \% OF $\%$ OF

Office Machinery/ NC TOOLS TOTAL NC MACHINE TOOLS

Other Machinery

Agricultural Machinery

$2142 \quad 22.0 \quad 1.6$

Telegraph \&

Telephone, etc.

Motor Vehicles

Aerospace

1118

0.3

Shipbuilding \& Marine
Construction Equipment

469

11.5

2.0

1037

4.8

0.4

1.7

2.9

0.7

Fig. 3. PRODUCTION OF NC MACHINE TOOLS AS PERCENTAGE OF ALL METAL CUTTING TOOLS, UK.

stock of NC tools to that of our competitors is less than the ratio of our GNPs, which suggests that we may well not get as much work out of them as do others. Moreover, the greatest concentrations of $\mathrm{NC}$ machines are in industries which manufacture things like office machinery or telecommunications equipment, rather than in, for example, the motor industry where they could provide more cash flow (Fig. 2). And in the Machine Tool field there is now a tendency for us to import high technology and to export low technology. Figures 3-5 show the production, import and export of NC machines, and demonstrate that we are net importers in that field.

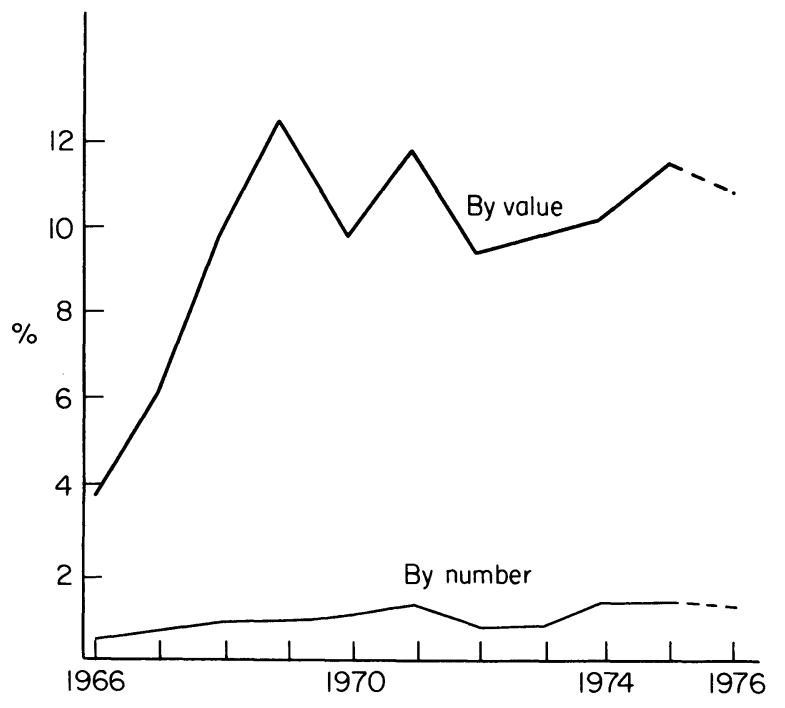

(Metalworking Production: Fourth Survey)

Fig. 4. PRODUCTION, EXPORT \& IMPORT OF NC MACHINE TOOLS BY NUMBER.

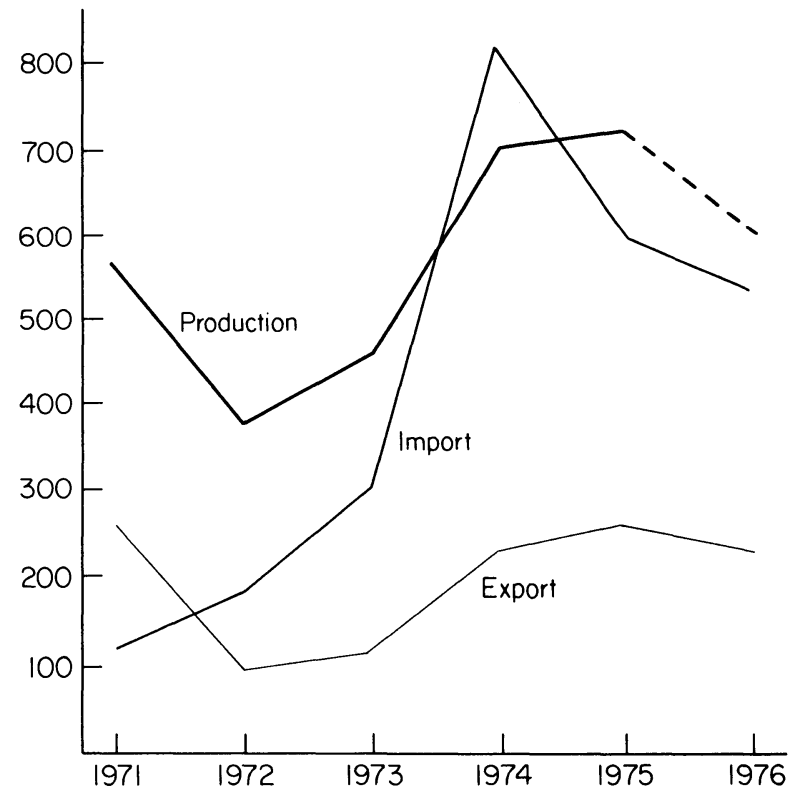

(Metalworking Production: Fourth Survey) 
Fig. 5. PRODUCTION, EXPORT AND IMPORT OF NC TOOLS BY VALUE.

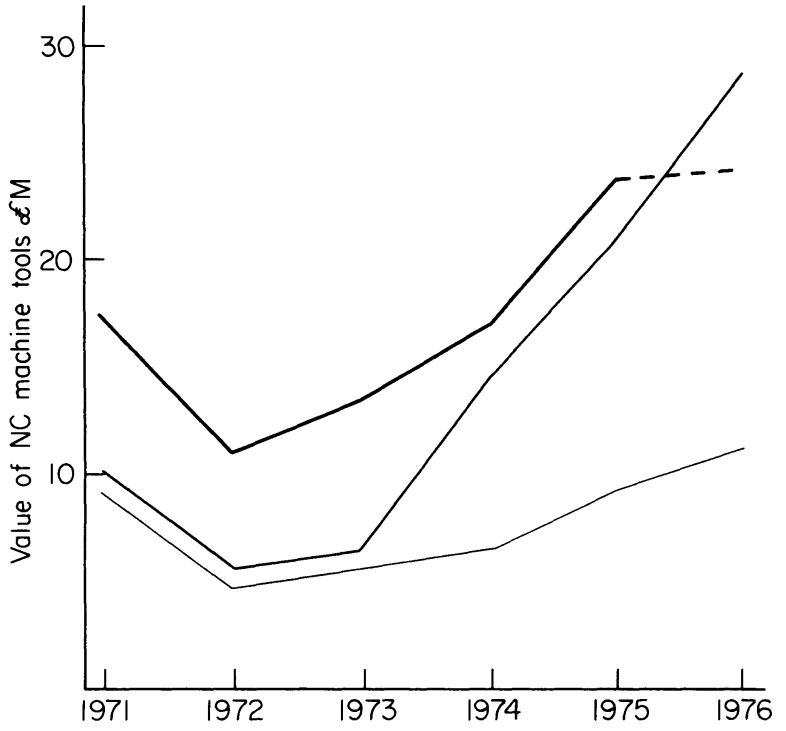

(Metalworking Production: Fourth Survey)

In other words, we seem to have yet another example of our characteristic national tendency to make a good start and then get overtaken. As a typical example, Direct Numerical Control (DNC) was invented and first applied in this country in 1968 with the Molins System 24, since when it has been rather ignored by the UK engineering industry but taken up fairly intensively in the USA, Japan and, more recently continental Europe. Now, however, it has been estimated that the UK is perhaps ten years behind its major competitors in the installation of linked systems of DNC and FMC-Flexible Manufacturing Systems linking machines by an automatic workpiece transport mechanism. It must be recognised that many of the installations abroad were acts of faith, not justified on strict economic grounds. NC promises to keep productivity in the small-batch end of manufacturing industry-some $40 \%$ of production from the engineering industry is work produced in batches of 50 or less-and should provide the batch manufacturer with the flexibility and enhanced productivity the mass producer already has.

Despite our loss of the lead, I am an optimist and I believe that the opportunity now to be seized is one that requires a departure from tradition. We are entering the microelectronic age, amid a flurry of activity in private and public sectors, and this might provide such an opportunity. This time we are certainly not the leaders after lap 1: we are trailing in laps 2, 3 and 4 . We therefore have to do what others have done to us previously. We must be selective and we must link the right technology to the market; that may not necessarily be the highest technology. Microelectronics will revolutionise much of industry; however, the machine tool industry is already acquainted with the ways of electronic control, and to you, the new technologies might provide impetus and a chance to alter direction rather than total upheaval. Microprocessors offer the opportunity to devolve downwards data processing and data storage; it will be possible to close the control loop at the machine possibly using parameters not commonly used, and of installing networks giving much greater flexibility and production than hitherto. It has been predicted that the average microcomputer, by 1990 , will be able to have the processing capability of a 1970 main-frame computer, and access to the same amount of store, so the potential is enormous.

Government does not want to intervene gratuitously and past experience both here and abroad (especially in Japan) seems to show that help with R\&D or design ("technology push") does not work in isolation: it must be linked to adequate investment, production capability, and critical markets. "Purchasing pull" may be necessary. The Department of Industry has recently set up the Automated Small-batch Production Committeethe ASP Committee-consisting largely of industrialists from a wide range of relevant companies to look into the problems. They believe we should be getting our feet wet, so as to be prepared for future generations of advanced systems. They have recommended that a number of pilot installations of intermediate systems be set up to provide information on reliability, cost-effectiveness and social acceptability, and to give the machine tool industry experience and an opportunity to compete in world markets; they recommended that the DoI should commission a study by industry on the design of a new range of NC tools and a contract is close to being placed; thirdly they recommended that a co-ordinated programme of $R \& D$, essential for the development in the UK of advanced systems, be started and two proposals have now gone to the Department's Mechanical Engineering and Machine Tools Requirements Board for support.

Within the Department the Machine Tools and Mechanical Engineering Division, the new Electronic Application Division, the National Engineering Laboratory and the Computer Aided Design Centre are all anxious to help and can direct industry to the several schemes available whereby Government can provide financial support for pump-priming. A proposal with a high innovatory content could qualify for support from MEMTRB, usually on a shared-cost basis; firms seeking help to launch a product or process from the design stage to the point of commercial production can apply to the Product and Process Development Scheme, while product development activity associated with major new investment projects in manufacturing industry may be eligible for assistance under the Selective Investment Scheme. The Microprocessor Application Scheme, recently launched, seeks to do just what the title implies, and includes a large educational element. 
Thus, advanced machine tools and systems do provide an opportunity to improve our output and productivity, especially in the smaller batchproducing industries. We must seize the opportunities, but we must be selective, as we cannot afford to do everything and we must match our technology to the market. We must face up to the social questions-on the one hand people are increasingly reluctant to do unpleasant work and to work shift and unsociable hours, on the other hand increased automation will produce a change in working patterns. If we are not in the business of manufacturing advanced systems we shall undoubtedly import them, and we would thus import unemployment in the machine tool industry. One thing is certain: we cannot contract out of the new technology, whose most important effect is to enable a better manufacturing job to be done, with better quality and more reliability in the final product. Attempts to retain the older, more labour intensive methods will not preserve employment, for the products will become less and less competitive in the market. Employment will be best safeguarded if we can use the new markets to former levels. In the 1930s, we used to think of quality (the Rolls-Royce) and the result of labour intensive craftsmanship, and mechanised mass production as being the method for producing the cheap but nasty Ford "tin-lizzie", and to think of quality and mechanisation as alternatives, to be traded off judiciously against one another. This idea still survives to some extent, and needs to be cast out, for it is stone dead. Numerical control is now an essential component of both quality and cost improvement alike. 


\section{In Memoriam}

\section{Professor Franz Koenigsberger}

\author{
M.Sc.Tech, D.Sc., Dipl.Ing, \\ Dr-Ing Eh, Dr hc, Hon. D. Tech., C.Eng., \\ F.I.Mech.E., Mem.A.S.M.E., F.I.P.Prod.E.
}

Professor Franz Koenigsberger, a machine tool engineer of international repute, died on 22nd January, 1979 in Manchester at the age of 71. From 1961 until his retirement in 1975 he occupied the first Chair of Machine Tool Engineering at the University of Manchester Institute of Science and Technology (UMIST), and was renowned for his contributions to the study of machine tool engineering. He was a co-founder of the International Conference in Machine Tool Design and Research and was the Chairman in the alternate years when it was held in Manchester.

He was born and educated in Germany and obtained his first degree (Dipl.Ing) at the University of Berlin. After four years' industrial experience in Germany, Belgium and Italy he came to England, spending a further nine years in industry, eight of which were as Chief Mechanical Engineer with Cooke and Ferguson Ltd., in Manchester. In 1947 he joined the Mechanical Engineering Department at UMIST serving as Lecturer, Senior Lecturer and Reader in Machine Tools and Production Processes before his appointment as Professor of Machine Tool Engineering.

He worked with the pioneering Professors of Machine Tools in the Technical University of Berlin in 1933 and in his work at UMIST raised the international status of his group and himself to the same high level as that of his Alma Mater. He devoted his professional life to the practice, design and research in Machine Tools and to the education of others in this field. He was an active member of the Institutions of Mechanical and Production Engineers (IMechE, IProdE) in Britain and of the International Institution for Production Engineering Research (CIRP), for which he served as President in 1966. To these bodies he presented many papers and lectures and was in great demand as a Chairman of technical sessions and committees. His achievements in the fields of Machine Tools and Production Engineering were recognised by prizes and medals awarded by professional institutions such as the IMechE, the IProdE, the CIRP and the Manchester Association of Engineers. His contributions to the studies in Machine Tool Engineering were further recognised by the award of Honorary Doctorates by the Universities of Berlin, Ghent and Bradford, the Honorary Fellowship of the Manchester Polytechnic and, on his retirement in 1975, by the conferment of the title Professor Emeritus by the University of Manchester.

A prolific writer, he was the author of five major text books, some of which have been translated into French, German, Turkish and Japanese, and of many other smaller works and articles. He also published over 100 papers in professional journals - being awarded the DSc degree in 1954 - and was for many years Editor of several international technical journals.

At UMIST Professor Koenigsberger initiated close collaboration with industry both in research and teaching. In particular he pioneered a special two year fulltime course in Machine Tool Design sponsored by the Machine Tool Trades Association which formed the basis for the MSc courses in Machine Tool Technology and Design and in Manufacturing Technology which followed. His collaboration with industry and research

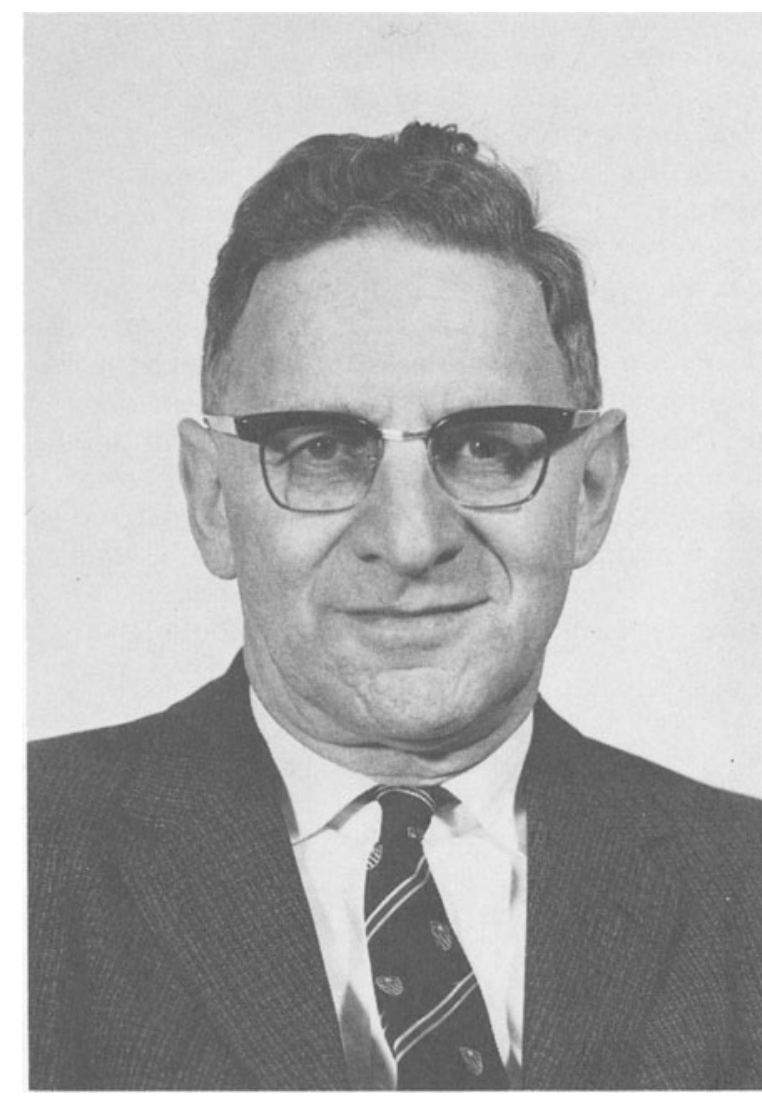

associations in this country and abroad led to much sponsored research and to the growth of his very active group which became the Division of Machine Tool Engineering within the Department of Mechanical Engineering. Under his direction the postgraduate student population grew to over 80 and its work and reputation grew as did the number of high level industrial and academic visitors from all over the world. In particular, his close collaboration and friendship with the late Professor Opitz of the Technical University of Aachen led to a fruitful exchange of staff and research workers. As a consultant to industry he was in great demand and many of his ex students are now to be found in high level positions in both Industry and Academic Institutions throughout the world.

In addition to his work throughout Britain and abroad Professor Koenigsberger took an active part in local interests. In 1965/66 he was the President of the Manchester Association of Engineers and in 1971 President of the Manchester Technology Association. $\mathrm{He}$ participated too in local youth and charitable associations.

$\mathrm{He}$ will also be remembered by his many colleagues and friends for his humanity, his unselfish readiness to help, his generosity and his vast fund of apposite anecdotes and stories for which he was never at a loss.

He had an enormous capacity for work and travelled widely all over the world at the invitation of Industry and Academic Institutions where his counsel was in great demand.

Professor Koenigsberger's reputation has enhanced the status not only of UMIST but of British Academic Institutions. He set standards which to many will seem impossible goals and his relatively sudden death has brought to an untimely end his still numerous international activities. He will be sorely missed.

$\mathrm{He}$ is survived by his devoted wife Lilli, son and daughter and grandchildren. 